\title{
Retooling Products to Reach New Markets: The Lindt Candy Dilemma
}

\author{
Kimberly Eddleston (Northeastern University)
}

KEYWORDS: Management of Companies \&

Enterprises, Sales, Marketing, Advertising, Accommodation \& Food Services, Management, Marketing, Teaching Methods, Product Development, Strategy.

\section{OVERVIEW}

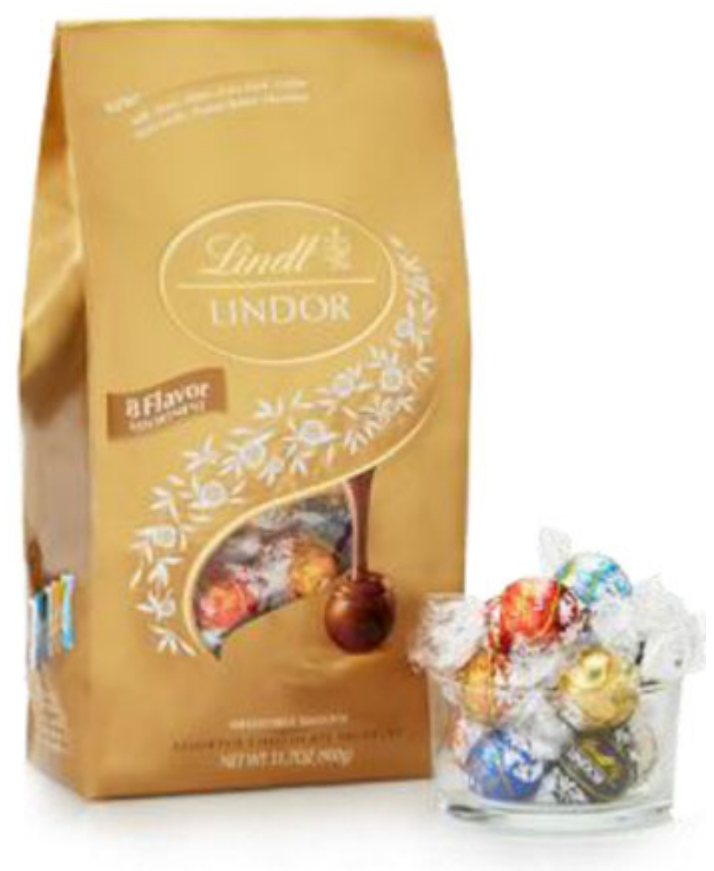

The purpose of this exercise is to help entrepreneurship students understand the importance of retooling products to reach new markets. In this exercise students are required to generate and then evaluate product ideas based on Lindt's already successful Lindor chocolate truffle ball. Students must then develop a total product offering for their retooled product, including branding, packaging and promotion strategies. This exercise has been successfully used with undergraduate, graduate and executive students in the U.S. and abroad. It is well-suited for the following topics: retooled/platform products, creativity, developing a total product offering, and product strategy.

\section{Introduction}

Entrepreneurial businesses live and die according to the quality of their ideas. Whenever possible entrepreneurs should consider retooling existing products and creating product platforms because they provide opportunities to leverage current product technologies into new markets and facilitate a reduction in cost of goods for product lines. By creating retooled products entrepreneurs can expand into new markets, which is essential for longterm growth. In addition, creating an effective total product offering for the retooled product is essential to achieve market success. Failure to understand product strategy options and the compatibility of the total product offering with the product can lead to ineffectiveness and conflict in the entrepreneur's marketing effort. Therefore, it is important that nascent entrepreneurs learn how to effectively retool products and create a complimentary total product offering since both significantly contribute to an entrepreneurial firm's survival and growth.

\section{THE EXERCISE}

To briefly describe the Lindt Candy Dilemma, this exercise requires teams of students to create new products for the Lindt candy company based on the company's already existing and successful Lindor chocolate truffle ball. The goal of the product development is to increase Lindt's market share. Each team of students is given a brief description of the dilemma and plenty of paper and colored markers to create a depiction of their retooled product. The teams are also required to create a total product offering for their new product including a brand name, slogan and advertising plan. Finally, teams present their retooled products and accompanying total product offering to the class. More specific directions are below. 


\section{Advance Preparation}

Materials for this exercise include paper and colored markers. It is also recommended that the instructor provide each team with at least one Lindor chocolate truffle ball so that the teams can examine and taste the candy. It is preferable if each team receives different flavor truffle balls so that the members can compare and contrast the flavors and textures. The instructor should also list the flavors of the truffle balls on the board. Bags which include multiple flavors can be used, however if these are not available the bag which includes the milk, dark and white chocolates will do fine. If the Lindor candies are not available the instructor can simply describe the candies and list the flavors of the candies on the board or use another candy that is not overly familiar to the students.

Before the exercise is performed, preferably the previous class, the instructor may choose to present some complimentary material to help students perform the exercise. This may include how a market opportunity grid can help entrepreneurs target markets and grow their businesses by targeting new markets (for an example, see Exhibit 3), guidelines for branding/naming a product (for an example, see Exhibit 4), and advantages and disadvantages of different advertising media (for an example, see Exhibit 4). The market opportunity grid can also be presented after the team presentations. For example, if the instructor chooses, he/she can have the class fill in the market opportunity grid with each team's product.

\section{Team size}

This exercise requires teams of three to seven students. Teams are best for this exercise because it allows students to experiment with different group-based creativity techniques including brainstorming and mindmapping. The exercise also requires students to coordinate their efforts in order to produce the total product offering. For example, while one student works on completing their candy's logo for presentation, other students can prepare the candy's advertising campaign. As such, by using teams for this exercise students have the opportunity to experience the benefits of using a team for creativity purposes, the need to effectively coordinate team members in order to complete the tasks of the exercise, the process of group decision-making, and general concepts of group dynamics.

\section{Approximate Timing}

The entire exercise, excluding presentations and discussion, is about one hour. The time allocations can be broken down as follows:

\section{Activity: Explanation of Exercise Time Required: 10 Minutes Assign students to teams of 3-7 members}

The goal of each team is to create a retooled product based on the Lindor chocolate truffle ball. The complete directions, as distributed to students, is included in Exhibit 1. The directions explain that Lindt is hoping to become a major player in the candy industry by retooling their successful Lindor chocolate truffle ball into a new product with greater market appeal. It is important that students understand that they will be retooling the Lindor candy - that is, their product should be based on the Lindor chocolate truffle ball. After creating their new product students will need to develop a total product offering including a brand name, slogan, packaging and advertising campaign.

Students often ask if they can develop more than one product. Here, instructors can choose to either limit the number of created products to one per team or allow them to create as many as they choose - but with the instruction that they will need to explain why the additional products are necessary in order to successfully reach their target market. For the most part, teams will develop only one product, but occasionally a team will develop several products that somehow compliment one another and would be expected to boost one another's sales. An example would be a tube of truffle-like filling that comes in various flavors that children could either directly squirt into their mouths or preferably, spread over separately sold chocolate wafers that would be packaged to resemble bubblegum baseball cards.

Instructors should instruct the students that they will be presenting their products and total product offering to the rest of the class at the end of the exercise. A typical presentation should include a description of the new product, its name and slogan (and logo if desired), a description of its packaging, and a brief explanation of the advertising plan that would be used to market the new product.

If the instructor wishes to create a bit of competition, which tends to heighten the students involvement and excitement, a panel of judges can be created by electing 
a representative from each team to choose the "best" product. If desired, the team with the "best" product can win a prize such as some candy (Lindt leftovers from the exercise) or an academic reward ( 2 bonus points on quiz). The team of judges evaluating the products should be instructed that they will need to explain why they chose a specific product as the "best" to the class.

\section{Activity: New Product Development Stage Time Required: $\mathbf{4 5}$ minutes}

During this stage students perform the actual exercise. The instructor may walk around the classroom to check with each team to see if there are any specific questions that he/she can help the students with. The instructor should also count down the time that is left, approximately every fifteen minutes. Otherwise, some teams never progress from idea generation to idea evaluation and selection. The countdown also helps them move from branding the product and producing a slogan to creating a complimentary advertising campaign.

\section{Activity: Presentation of Products Time Required: 15-20 minutes}

Each team of students presents their new product idea to the class and its accompanying advertising campaign. If possible, it is also useful to display each team's proposal by taping them on the wall. Teams can usually present their ideas and total product offering in 5-8 minutes. After the presentations are complete, the judges can evaluate the new product ideas and choose a winner. The instructor should advise the judges that they will need to explain their evaluation criteria and reasoning for their choice when they present the winner. Once the exercise is complete, class discussion can take place for the remainder of the class period.

\section{Discussion}

This exercise is effective in introducing entrepreneurship students to product strategy options and new product development. Either before or after the exercise, the Lindt Candy Dilemma is conducive to the discussion of the product development process and product strategy alternatives. By presenting material on the product development process and product strategy alternatives before the exercise the students have the opportunity to put into practice the techniques and strategies that they have learned so that they can consciously consider them while they create their new product and total product offering. Alternatively, the instructor can use the exercise to introduce the discussion of effective new product development and product strategies.

Invariably there are teams of students who develop multiple products for multiple markets, multiple products for one market, or one product for multiple markets. The results from the exercise often give clear examples of the differences among the product strategy options and the advantages and disadvantages of each. It also nicely leads to a discussion on how firms can increase their profits by selling more products to existing customers. Other entrepreneurship topics that this exercise effectively supports include the discussion of product life cycles, turning creative ideas into innovations, how to grow a business by reaching new markets, types of product development projects (i.e. derivatives, platform, breakthrough), creating a total product offering, and image compatibility in developing an effective advertising campaign.

Once the exercise is complete, classroom discussion can take place. A good way to facilitate the discussion is to first have each team answer the questions that will later be discussed as a class. Questions used for discussion with this case can be found in Exhibit 2. These include:

\section{What was the most difficult aspect in retooling the product? Why?}

Students tend to mention that idea generation was the easy part, especially since they had something to work with that had previously been proven to be successful the Lindor chocolate truffle ball. The hard part was evaluating the ideas and selecting the "right" product to develop into a total product offering. This often leads to a discussion on the evaluation criteria they used to select their final products. Teams that develop more than one version of a product will point out that they wanted to create a family of platform products that were based on some competitive advantage, but agreeing on exactly what was the competitive advantage of the Lindor chocolate truffle ball was difficult. This can be a good time to talk about the most effective techniques for retooling products and creating platform products to reach new markets. To focus the exercise more on creativity, this is the opportune time to discuss the creative process and techniques for evaluating ideas for their market potential. 


\section{How do you think developing a new product from scratch and retooling a product for a new market differ? What are the advantages and disadvantages of each?}

Students recognize that retooling a product tends to be a less risky endeavor than developing a new product from scratch because in retooling a product they have the chance to build on something that has previously been proven to be successful. They also recognize that retooling a product for a new market is "smart" since it capitalizes on a business's success and can significantly contribute to a business's growth However, they also point out that just because a product component worked in another market (i.e. common examples mentioned are flavors, shape, size) does not necessarily mean that they will be successful in a new market. Additionally, students may recognize challenges from cannibalization that their new product produces. Therefore, even though they had something to build upon in retooling their products, they still needed to think about the feasibility of their ideas in gaining market share and sales.

\section{What was the image that you wanted to project with the brand name and slogan you created for your product? How is this similar to or different from the image of the Lindor chocolate truffle balls?}

In answering this question students will often point out how other teams' new product image was not compatible with the image that Lindt had previously established and seemed to prosper from (i.e. high quality, Swiss chocolates). In their defense, these teams will quickly point out that they were targeting a completely new market - one that was not aware of Lindt's current image, or that they were purposefully trying to create a unique image for their product, independent of that of Lindt's, so as to more aggressively go after a new target market that does not find Lindt appealing. This question often leads to a very rich discussion on the complexities of creating a successful image for an entrepreneurial firm. The instructor can choose to discuss the benefits of creating an image for a product that is compatible with a business's current one and the reasons why a firm may choose to create a new, unique image for a product in their product line. This is also a good time to talk about how an entrepreneur needs to ensure that a product's name, slogan and packaging are consistent with the actual product being offered. For example, students will quickly point out if a team created a product for children (in brand name, packaging and advertising) that does not sound appealing in taste to children (i.e. small amaretto flavored candy pieces packaged similar to M\&M's and called Itty Bitty Lindt's).

\section{How will the new advertising plan help Lindt to expand into a new target market?}

Entrepreneurship students typically enjoy talking about advertising and marketing their product ideas. They will discuss how an advertising campaign needs to be tailored to reach their desired market most effectively. The issue of compatibility will often be mentioned again, specifically, making sure that an advertising campaign does not send mixed messages to consumers. That is, the firm wants to attract new customers while keeping the old; it does not want to attract new customers and lose the old. If the instructor chooses, this is a good opportunity to discuss cost-effective ways for an entrepreneur to advertise.

\section{In performing this exercise, what lessons did you learn about new product development?}

The purpose of this question is to make sure that the students understood the purpose of the exercise. By asking students to report their comprehension of material immediately after the exercise, they are more likely to clarify their understanding of the material at hand and think through their perceptions of the exercise and lessons involved. Answers to this question tend to be very diverse, but center on the following topics: creativity (i.e. how it is easier to generate ideas than select ideas, how much easier it is to develop retooled products than breakthrough products; how diverse the class's ideas were despite the fact that they were all based on the same Lindor chocolates), the advantages of creating retooled and platform products (i.e. to reach new markets, sustain growth, take advantage of a competitive advantage), the importance of creating a compatible total product offering (i.e. how the chosen name, slogan and packaging can mean the difference between success and failure, how product line compatibility can enhance a firm's image and market share), and how product additions need to fit the overall strategy of a firm.

\section{CONCLUSION}

This exercise offers students the opportunity to 
experience the entire product development process. Two common ways that small businesses can grow include getting their current customers to buy more products from them or by attracting new customers. As such, it is important for entrepreneurs to learn how to retool products so as to be attractive to their existing customers and/or to be attractive to new customers. This exercise allows students to experiment with creating new products in order to increase their market share. While some will choose to pursue the additional sales of existing customers, others will decide to pursue the business of new customers. Students also have the chance to create a name, slogan, packaging and advertising campaign for their products. All of these tasks are vital to an entrepreneurial business's success and this exercise is an appropriate tool to demonstrate that importance. By participating in this exercise students will experience the creative process, the benefits of creating retooled products, and the importance of a product development strategy.

\section{EXHIBIT 1: Lindt's Candy Dilemma: A Creativity Exercise in Retooling Products to Reach New Markets}

One of Lindt's most popular products is its Lindor chocolate truffle ball. In their stores, they sell these chocolate balls packaged in various quantities from a single piece to large 45-piece bags. During the holiday seasons they often package the chocolate balls in specialty boxes and packages in various sizes. In order to reach a larger market, Lindt also sells their individual chocolate pieces in other retail establishments. These retail establishments include gourmet stores, drug stores and gas stations. While this strategy has boosted sales and product brand recognition, particularly in areas where Lindt stores do not exist, it has not proven to be as successful in capturing market share as they had hoped. Executives at Lindt are looking to increase their market share and become a major player in the candy industry. However, they recognize that this will be hard.

Currently, Lindt is considered to be a fine, gourmet Swiss chocolate whose main target market is gift-giving adults, twenty years and older. In order to increase their market share and sales, Lindt will need to retool their product so that their product will be desirable by a larger target market. They want to do this while still capitalizing on the fact that their chocolates are of the highest quality and Swiss craftmanship. To reach their goals, Lindt executives have given teams in their marketing department the following task: Retool the Lindor chocolate truffle balls to appeal to a new target market and build a total product offering strategy to sell the new, retooled product. The team that develops the best product offering will win a significant bonus prize.

In short, here are your tasks:

1. Retool the Lindor chocolate truffle balls in a way that they will increase Lindt's market share and sales. This can include such modifications as resizing, reshaping, repackaging...

2. Based on the image that you want to project, develop a brand name and slogan for your new product. If you desire, a logo may also be developed. (A logo is a symbol which, when seen, instantly recalls your business. An example is Ralph Lauren's polo).

3. Develop an advertising plan. This includes deciding on what media to primarily use (and why), and coming up with an advertisement for that media source (i.e. a magazine advertisement, a radio advertisement, a television commercial, social media).

4. Your team will be responsible for presenting your total product offering to Lindt executives.

\section{EXHIBIT 2: DISCUSSION}
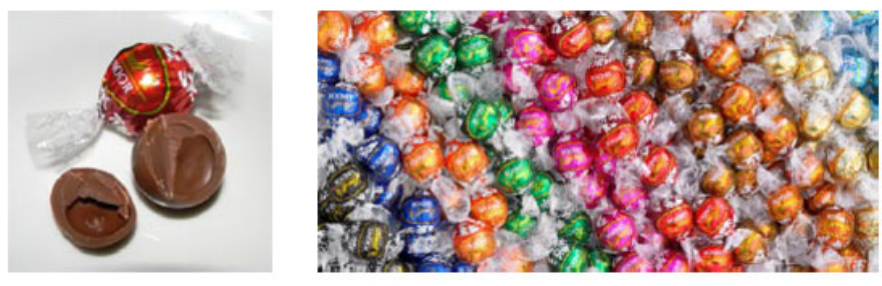

1. What was the most difficult aspect in retooling the product? Why?

2. How do you think developing a new product from scratch and retooling a product for a new market differ? What are the advantages and disadvantages of each?

3. What was the image that you wanted to project with the brand name and slogan you created for your product? How is this similar to or different from the image of the Lindor chocolate truffle balls?

4. How will the new advertising plan help Lindt to 
expand into a new target market?

5. In performing this exercise, what lessons did you learn about new product development? How does this exercise relate to new product development in the "real world"?

EXHIBIT 3: MARKET OPPORTUNITY GRID - THE CANDY MAP*

\begin{tabular}{l|l|l|l|l|}
\multicolumn{1}{c}{ Children } & \multicolumn{1}{c}{ Teens } & \multicolumn{1}{c}{ Adults } & \multicolumn{1}{c}{ Elderly } \\
\cline { 2 - 5 } Healthy & & & & \\
\cline { 2 - 5 } Gifting & & & Lindt & \\
Hunger & & & & \\
\cline { 2 - 5 } & & & & \\
\cline { 2 - 5 } & & & &
\end{tabular}

*Adapted from Meyer, M. H., Willcocks, N., \& Boushell, B. (2008). Corporate Venturing: An Expanded Role for R\&D. Research Technology Management, 51(1), 34-42. Children Teens Adults Elderly

\section{EXHIBIT 4: EXAMPLES OF}

\section{BACKGROUND MATERIAL TO SUPPORT EXERCISE}

I. Guidelines for Branding/Naming a Product:

1. Select a name that is easy to pronounce and remember

2. Choose a descriptive name (one that is consistent with the image that you want to project and helps you position the product in the market)

3. Use a name that can have legal protection

4. Select a name with promotional possibilities

II. Advantages and Disadvantages of Traditional Advertising Media

\begin{tabular}{|c|c|c|}
\hline Medium & Advantages & Disadvantages \\
\hline Newspaper & $\begin{array}{l}\text { Broad coverage in a selected geographic area; } \\
\text { Flexibility \& speed in bringing to print; } \\
\text { Generates sales quickly; Costs little }\end{array}$ & $\begin{array}{l}\text { May reach more than target market; } \\
\text { Difficult to attract reader attention; } \\
\text { Short life }\end{array}$ \\
\hline Direct Mail & $\begin{array}{l}\text { Targets specific customers; More sales with } \\
\text { fewer dollars; More information provided }\end{array}$ & $\begin{array}{l}\text { Not suitable for all products; Response } \\
\text { rate can be very low }\end{array}$ \\
\hline Magazines & $\begin{array}{l}\text { Can target special interests; More credible } \\
\text { than newspapers: Good reproduction, especially } \\
\text { for color; Relatively long advertising life }\end{array}$ & $\begin{array}{l}\text { Expensive to design, produce \& place; } \\
\text { Slow audience build-up; Limited } \\
\text { demonstration capabilities; Lack of urgency }\end{array}$ \\
\hline Radio & $\begin{array}{l}\text { Good for local or regional advertising } \\
\text { Low cost; Immediacy of message; Can be } \\
\text { scheduled on short notice; Entertaining }\end{array}$ & $\begin{array}{l}\text { Can't be a one-shot ad, must do several; } \\
\text { No visual treatment; Short advertising life } \\
\text { of message; Commercial clutter }\end{array}$ \\
\hline Television & $\begin{array}{l}\text { People can see \& hear about product/service; } \\
\text { Can target at national, regional or local level; } \\
\text { Ability to reach wide, diverse audience; } \\
\text { Immediacy of messages; Entertaining; } \\
\text { Demographic selectivity with cable stations }\end{array}$ & $\begin{array}{l}\text { Expensive for both production \& } \\
\text { on-air time; Must be repeated frequently; } \\
\text { Commercial clutter; Long lead } \\
\text { times required for production }\end{array}$ \\
\hline $\begin{array}{l}\text { Internet } \\
\text { (Social Media) }\end{array}$ & $\begin{array}{l}\text { Increases accessibility \& brand recognition; } \\
\text { Encourages customer engagement } \& \text { feedback; } \\
\text { Fast response; Broad reach; Low cost }\end{array}$ & $\begin{array}{l}\text { Requires much effort to be successful; } \\
\text { Lack total control over content }\end{array}$ \\
\hline
\end{tabular}

\section{More ideas}

College business professors looking for more ideas to enrich the classroom experience can find them here (https://eiexchange.com/eix-in-class) .

Additional Search Terms: entrepreneurship courses, teaching ideas, teaching resources, classroom ideas, entrepreneurship classes, business schools, business school classes, entrepreneurship students, professors 